\title{
The Associations between Exclusive Breastfeeding, Complementary Feeding, and the Risk of Stunting in Children Under Five Years of Age: A Path Analysis Evidence from Jombang East Java
}

\author{
Baroroh Barir'1), Bhisma Murti²), Eti Poncorini Pamungkasari3) \\ 1)Masters Program in Nutrition, Universitas Sebelas Maret \\ 2)Masters Program in Public Health, Universitas Sebelas Maret \\ 3)Faculty of Medicine, Universitas Sebelas Maret
}

\begin{abstract}
Background: Stunting in children becomes a health problem that gets priority and must be addressed immediately. Delayed development, a decrease in cognitive function and immune function and the risk of diabetes mellitus, coronary heart disease, hypertension and obesity are the effects of stunting. This study aimed to analyze the determinants of stunting in children aged 2-3 years in Jombang, East Java.

Subjects and Method: This was an analytic observational study with case control design. The study was carried out at Plandaan and Kabuh community health centers, Jombang, East Java, from March to April 2019. A sample of 200 children aged 2-3 years old was selected by fixed disease sampling. The dependent variable was stunting. The independent variables were maternal age, maternal height, maternal attitudes, maternal occupation, birth length, infant birth weight, exclusive breastfeeding, breastfeeding, family income, mother's education, and mother's knowledge. The data collection was done using questionnaires and analyzed with path analysis.

Results: Stunting was directly and negatively affected by birth length $\geq 48 \mathrm{~cm} \mathrm{(b=-2.37;95 \%} \mathrm{CI=}$ -3.25 to $-1.50 ; \mathrm{p}<0.001)$, infant birth weight $\geq 2500 \mathrm{~g}(\mathrm{~b}=-1.43 ; 95 \% \mathrm{CI}=-2.53$ to $-0.32 ; \mathrm{p}=0.011)$, exclusive breastfeeding $(\mathrm{b}=-1.09 ; 95 \% \mathrm{CI}=-1.90$ to $-0.28 ; \mathrm{p}=0.008)$, and timely complementary feeding $(b=-1.09 ; 95 \% \mathrm{CI}=-1.94$ to $-0.24 ; \mathrm{p}=0.012)$. Stunting was indirectly affected by family income, maternal age, maternal attitude, maternal height $>150 \mathrm{~cm}$, employed mother, maternal education, and maternal knowledge.

Conclusion: Stunting is directly and negatively affected by birth length $\geq 48 \mathrm{~cm}$, birth weight $\geq$ $2500 \mathrm{~g}$, exclusive breastfeeding, timely complementary feeding. It was indirectly affected by family income, maternal age, attitude, maternal height $>150 \mathrm{~cm}$, employment, education, and knowledge.
\end{abstract}

Keywords: stunting, determinants, path analysis

\section{Correspondence:}

Baroroh Barir. Masters Program in Nutrition, Universitas Sebelas Maret, Jl. Ir. Sutami No. 36 A, Surakarta 57126, Central Java. Email:barorohbarir5@gmail.com.Mobile: +6281331940865.

\section{BACKGROUND}

One of the goals in the health sector, the Sustainable Development Goals (SDGs) mentions the target of community nutrition, namely in 2030, ending all forms of malnutrition, including achieving the international target of 2025 for reducing stunting and wasting for children under five (Ministry of Health, 2015). The government pays attention to stunting in children under the age of $2-3$, one of which is through the national and international nutrition movement, namely the Scaling Up Nutrition (SUN) movement (Singh, 2016). Stunting events in the world are estimated at around $22.2 \%$ of children under five. The results of basic health research (2018) in Indonesia, in 2013 around $37.2 \%$ of children under five 
were stunting and dropped to $30.8 \%$ with the fifth largest prevalence of stunting. Stunting will have an impact on the level of intelligence and be more vulnerable to disease and increase poverty and widen inequality (Kusumawati et al., 2015).

Stunting is influenced by low maternal education factors, height $<145 \mathrm{~cm}$, age $<20$ years and $\geq 35$ years, lack of knowledge and negative maternal attitudes. Armstrong et al (2011) stated that the level of education caused stunting because of the lack of the ability of mothers to receive information about nutrition. Other factors were maternal height $<150 \mathrm{~cm}$ due to pathological conditions such as deficiency of plant hormones and increased chances of inheriting these genes so that children grow into stunting (Onis and Branca, 2016).

Huda et al. (2017) explained that the lack of maternal knowledge related to health behavior and environmental hygiene had an effect on the occurrence of infectious diseases as well as mothers who worked at risk of having stunting children because of the lack of maternal attention to children's nutritional needs. Akram et al (2018) also explained that stunting is affected by the administration of MP-ASI too early.

\section{SUBJECTS AND METHOD \\ 1. Study Design \\ This was an analytic observational study with case control design. The study was conducted at Plandaan and Kabuh commu- nity health centers, Jombang, East Java, from March to April 2019.}

\section{Population and Samples}

The source population in this study was from all stunting children aged 2-3 years at Plandaan and Kabuh community health centers, Jombang, East Java. A sample of 200 children aged 2-3 years old was selected by fixed disease sampling.

\section{Study Variables}

The dependent variable was stunting. The independent variables were maternal age during pregnancy, maternal height, attitude, employment status, birth length, birth weight, exclusive breastfeeding, complementary feeding, family income, maternal education, and maternal knowledge.

\section{Operational Definition of variables}

Stunting. Stunting was the value of calculating height for children aged 2 - 3 years according to age which is expressed by standard deviation, in which the value of Zscore <- 2 SD, measured by microtoise.

Maternal age. Maternal age was age based on date of birth on birth certificate when retrieving data in years, measured by questionnaire.

Maternal height. Maternal height was height based on anthropometric measurements, measured by microtoise.

Birth length. Birth length was the length measured after birth and recorded in the maternal and child health book.

Birth weight. Birth weight was a measure of a child's weight weighed shortly after birth and recorded in maternal and child health book.

Exclusive breastfeeding. Exclusive breastfeeding was breastfeeding without the addition of any food or drink to children from birth to age 6 months. It was measured by questionnaire.

Family income. Family income was the average amount of fixed and side income from the family head, mother and other family members in the last 1 month. It was measured by questionnaire.

Maternal education. Maternal education was the last formal education attained by mother. It was measured by questionnaire. Maternal knowledge. Maternal knowledge was maternal ability to answer questions about good nutrition for pregnant women. It was measured by questionnaire. 
Journal of Maternal and Child Health (2019), 4(6): 486-498

https://doi.org/10.26911/thejmch.2019.04.06.09

Maternal attitude. Maternal attitude was the response of the beliefs held by pregnant women to nutritional intake that must be consumed and fulfilled, during pregnancy in the form of positive or negative response. It was measured by a questionnaire.

Maternal occupation. Maternal occupation was a form of activity carried out by the subjects to earn income. It was measured by a questionnaire.

\section{Data Analysis}

Univariate analysis was performed to see the frequency distribution and the percentage of the characteristics of the study subjects. Bivariate analysis was conducted to study the relationship between stunting and independent variables using chisquare. Multivariate analysis carried out using path analysis run on Stata 13. Step of of path analysis was model specification, model identification, model fit, parameter estimation, and model re-specification.

\section{Research Ethics}

Research ethics included informed consent, anonymity, confidentiality, and research ethics. Research ethics was obtained from Faculty of Medicine, Universitas Sebelas Maret, Surakarta with number 114/ UN27.06/KEPK/2019.

1. Sample Characteristics

The study subject was 200 children aged 23 years old in Jombang, East Java. Sample characteristic was described in Table 1.

Table 1 shows that almost all of 155 subjects or $87.5 \%$ had birth lengths $\geq 48$ $\mathrm{cm}$, birth weight $\geq 2,500 \mathrm{~g}$ (87.5\%), exclusive breastfeeding (61.0\%), timely complementary feeding was 136 children (68.0\%). As many as 159 mothers (79.5\%) were at healthy reproductive age $(<20$ or $>35$ years old). Half of the study subjects had low income (50.5\%). Mostly (93.5\%) of maternal height was $>150 \mathrm{~cm}$.

\section{Bivariate Analysis}

Bivariate analysis was used to see the correlation between independent variables of maternal age, maternal height, maternal attitude, maternal occupation, birth length, infant birth weight, exclusive breastfeeding, breastfeeding, family income, maternal education and knowledge of mothers with dependent variable stunting based on the results in Table 2.

Table 2 shows the results of bivariate analysis. Table 2 shows that birth length $\geq$ $48 \mathrm{~cm}(\mathrm{OR}=0.07 ; \mathrm{p}<0.001)$, birth weight $\geq 2500$ g (OR $=0.14 ; \mathrm{p}<0.001)$, exclusive breastfeeding ( $\mathrm{OR}=0.22 ; \mathrm{p}<0.001)$, timely complementary feeding $(\mathrm{OR}=0.35 ; \mathrm{p}=$ 0.002), family income $(\mathrm{OR}=0.05 ; \mathrm{p}=$ o.041), positive attitude $(\mathrm{OR}=0.33 ; \mathrm{p}=$ $0.001)$ reduced the risk of stunting.

Age at high risk of pregnancy $(\mathrm{OR}=$ $0.76 ; \mathrm{p}=0.500$ ), working outside the home $(\mathrm{OR}=1.13 ; \mathrm{p}=0.722)$, good maternal knowledge $(\mathrm{OR}=0.90 ; \mathrm{p}=0.743)$, high maternal education $(\mathrm{OR}=1.00 ; \mathrm{p}=1,000)$, maternal height $>150 \mathrm{~cm}$ was statistically not significant with stunting.

\section{Path Analysis}

Figure 1 shows the structural model after estimation using STATA and shows the suitability of the path analysis model as follows:

Table 3 shows that there was a direct and negative influence on birth weight on stunting, and the effect was statistically significant. Children who were born at gram 2500 grams had logods for stunting of 1.43 units lower than those with birth weight <2500 grams (b = -1.43; 95\% CI 2.53 to -0.32; $\mathrm{p}=0.011$ ). There was a direct and negative influence on birth length on stunting, and the effect was statistically significant. Children whose birth length $\geq$ $48 \mathrm{~cm}$ had a logodd for stunting of 2.37 units lower than children with birth length $<48 \mathrm{~cm}(\mathrm{~b}=-2.37$; CI $95 \%-3.25$ to -1.50 ; $\mathrm{p}$ 
$<0.001)$. There was a direct and negative effect of timely complementary feeding on stunting. Timely complementary feeding reduced logodd of stunting 1.09 units $(b=-$ 1.09; $95 \% \mathrm{CI}=-1.94$ to $-0.24 ; \mathrm{p}=0.012)$. There was a direct and negative effect of exclusive breastfeeding on stunting. Exclusive breastfeeding decreased logodd of Table1. Subjects Characteristics

\begin{tabular}{|c|c|c|}
\hline Characteristics & Frequency (n) & Percentage (\%) \\
\hline \multicolumn{3}{|l|}{ Birth Body Length } \\
\hline$<48 \mathrm{~cm}$ & 45 & 22.5 \\
\hline$\geq 48 \mathrm{~cm}$ & 155 & 87.5 \\
\hline \multicolumn{3}{|l|}{ Infant Birth Weight } \\
\hline$<2500$ gram & 25 & 12.5 \\
\hline$\geq 2500$ gram & 175 & 87.5 \\
\hline \multicolumn{3}{|l|}{ Exclusive breastfeeding } \\
\hline No & 78 & 39.0 \\
\hline Yes & 122 & 61.0 \\
\hline \multicolumn{3}{|l|}{ Complementary feeding } \\
\hline Not on time & 64 & 32.0 \\
\hline On time & 136 & 68.0 \\
\hline \multicolumn{3}{|l|}{ Stunting } \\
\hline No Stunting & 150 & 75.0 \\
\hline Stunting & 50 & 25.0 \\
\hline \multicolumn{3}{|l|}{ Maternal Age } \\
\hline$\geq 20-35$ years & 159 & 79.5 \\
\hline$<20$ years or $>35$ years & 41 & 20.5 \\
\hline \multicolumn{3}{|l|}{ Maternal education } \\
\hline Low (<Senior high school) & 112 & 56.0 \\
\hline High ( $\geq$ Senior high school) & 88 & 44.0 \\
\hline \multicolumn{3}{|l|}{ Maternal occupation } \\
\hline Working at home & 140 & 70.0 \\
\hline Working outside the house & 60 & 30.0 \\
\hline \multicolumn{3}{|l|}{ Family Income } \\
\hline Low $(<\operatorname{Rp} 1,800,000)$ & 101 & 50.5 \\
\hline High ( $\geq \operatorname{Rp} 1,800,000)$ & 99 & 49.5 \\
\hline \multicolumn{3}{|l|}{ Maternal height } \\
\hline$<150 \mathrm{~cm}$ & 13 & 6.5 \\
\hline$\geq 150 \mathrm{~cm}$ & 187 & 93.5 \\
\hline \multicolumn{3}{|l|}{$\overline{\text { Attitude }}$} \\
\hline Negative & 69 & 34.5 \\
\hline Positive & 131 & 65.5 \\
\hline \multicolumn{3}{|l|}{ Maternal knowledge } \\
\hline Poor & 92 & 46.0 \\
\hline Good & 108 & 54.0 \\
\hline
\end{tabular}

stunting 1.09 units $(\mathrm{b}=-1.09 ; 95 \% \mathrm{CI}=-$ 1.90 to $-0.28 ; \mathrm{p}=0.008)$. There was an indirect and positive effect of family income on stunting through infant birth. Children with high family income had logodd to experience normal birth weight of 1.01 units higher than low family income $(b=1.01$; $95 \% \mathrm{CI}=0.08$ to $1.95 ; \mathrm{p}=0.033$ ). 
Journal of Maternal and Child Health (2019), 4(6): 486-498

https://doi.org/10.26911/thejmch.2019.04.06.09

Table2. BivariateAnalysis

\begin{tabular}{|c|c|c|c|c|c|c|c|c|}
\hline \multirow{3}{*}{ Independent Variables } & \multicolumn{4}{|c|}{ Stunting } & \multirow{2}{*}{\multicolumn{2}{|c|}{ Total }} & \multirow{3}{*}{$\mathbf{O R}$} & \multirow{3}{*}{$\mathbf{p}$} \\
\hline & \multicolumn{2}{|c|}{ No } & \multicolumn{2}{|c|}{ Yes } & & & & \\
\hline & $\mathbf{N}$ & $\%$ & $\mathbf{N}$ & $\%$ & $\mathbf{N}$ & $\%$ & & \\
\hline \multicolumn{9}{|l|}{ Birth height } \\
\hline$<48 \mathrm{~cm}$ & 15 & $33 \cdot 3$ & 30 & 66.7 & 45 & 100 & 0.07 & $<0.001$ \\
\hline$\geq 48 \mathrm{~cm}$ & 135 & 87.1 & 20 & 12.9 & 155 & 100 & & \\
\hline \multicolumn{9}{|l|}{ Birth weight } \\
\hline$<2500 \mathrm{~g}$ & 9 & 36.0 & 16 & 64.0 & 25 & 100 & 0.14 & $<0.001$ \\
\hline$\geq 2500 \mathrm{~g}$ & 141 & 80.6 & 34 & 19.4 & 175 & 100 & & \\
\hline \multicolumn{9}{|l|}{ Exclusive breastfeeding } \\
\hline No & 45 & 57.7 & 33 & 42.3 & 78 & 100 & 0.22 & $<0.001$ \\
\hline Yes & 105 & 86.1 & 17 & 13.9 & 122 & 100 & & \\
\hline \multicolumn{9}{|l|}{ Complementary feeding } \\
\hline Late & 39 & 60.9 & 25 & 39.1 & 64 & 100 & 0.35 & 0.002 \\
\hline Timely & 111 & 81.6 & 25 & 18.4 & 136 & 100 & & \\
\hline \multicolumn{9}{|l|}{ Family Income } \\
\hline Low $(<\operatorname{Rp} 1,800,000)$ & 68 & 68.7 & 31 & 31.3 & 99 & 100 & 0.051 & 0.041 \\
\hline High $(\geq \operatorname{Rp} 1,800,000)$ & 82 & 81.2 & 19 & 18.8 & 101 & 100 & & \\
\hline \multicolumn{9}{|l|}{ Maternal Age } \\
\hline Healthy Reproduction Age & 113 & 73.9 & 40 & 26.1 & 153 & 100 & 0.76 & 0.500 \\
\hline High Risk Age & 37 & 78.7 & 10 & 26.1 & 47 & 100 & & \\
\hline \multicolumn{9}{|l|}{ Maternal Attitude } \\
\hline Negative & 42 & 60.9 & 27 & 39.1 & 69 & 100 & & \\
\hline Positive & 108 & 82.4 & 23 & 17.6 & 131 & 100 & 0.33 & 0.001 \\
\hline \multicolumn{9}{|l|}{ Occupation } \\
\hline At home & 106 & 75.6 & 34 & 24.3 & 140 & 100 & & \\
\hline Outside of home & 44 & $73 \cdot 3$ & 16 & 26.7 & 60 & 100 & 1.13 & 0.722 \\
\hline \multicolumn{9}{|l|}{ Knowledge } \\
\hline Poor & 68 & 73.9 & 24 & 26.1 & 92 & 100 & & \\
\hline Good & 82 & 75.9 & 26 & 24.1 & 108 & 100 & 0.90 & 0.743 \\
\hline \multicolumn{9}{|l|}{ Education } \\
\hline Low (< SHS) & 84 & 75 & 28 & 25.0 & 112 & 100 & 1000 & 1000 \\
\hline High ( $>$ SHS) & 66 & 75.0 & 22 & 25.0 & 88 & 100 & & \\
\hline \multicolumn{9}{|l|}{ Maternal Height } \\
\hline$<150 \mathrm{~cm}$ & 30 & 71.4 & 12 & 28.6 & 42 & 100 & 0.79 & 0.548 \\
\hline$\geq 150 \mathrm{~cm}$ & 120 & 75.9 & 38 & 24.1 & 158 & 100 & & \\
\hline
\end{tabular}

There was an indirect and negative effect of maternal age on stunting through infant birth weight, and the effect was statistically significant. Children of maternal age who were at high risk of having logodd to experience a normal baby's birth weight are 1.10 units lower than the age of mothers who had healthy reproductions $(b=-1.10$; 95\% CI $=-2.00$ to $-0.19 ; \mathrm{p}=0.018)$. There was an indirect and positive influence of the mother's attitude towards stunting through complementary feeding and exclusive breastfeeding, and the effect was statistically significant. Children with positive maternal attitudes had logodd to experience timely complementary feeding of 0.79 units higher than negative maternal attitude $(b=0.79$; 95\% $\mathrm{CI}=0.17$ to $1.40 ; \mathrm{p}=0.012)$. Children with positive maternal attitude had logodd for experience exclusive breastfeeding of 0.75 units higher than negative maternal 
attitude $(b=0.75 ; 95 \% \mathrm{CI}=0.14$ to $1.34 ; \mathrm{p}=\quad 0.014)$.

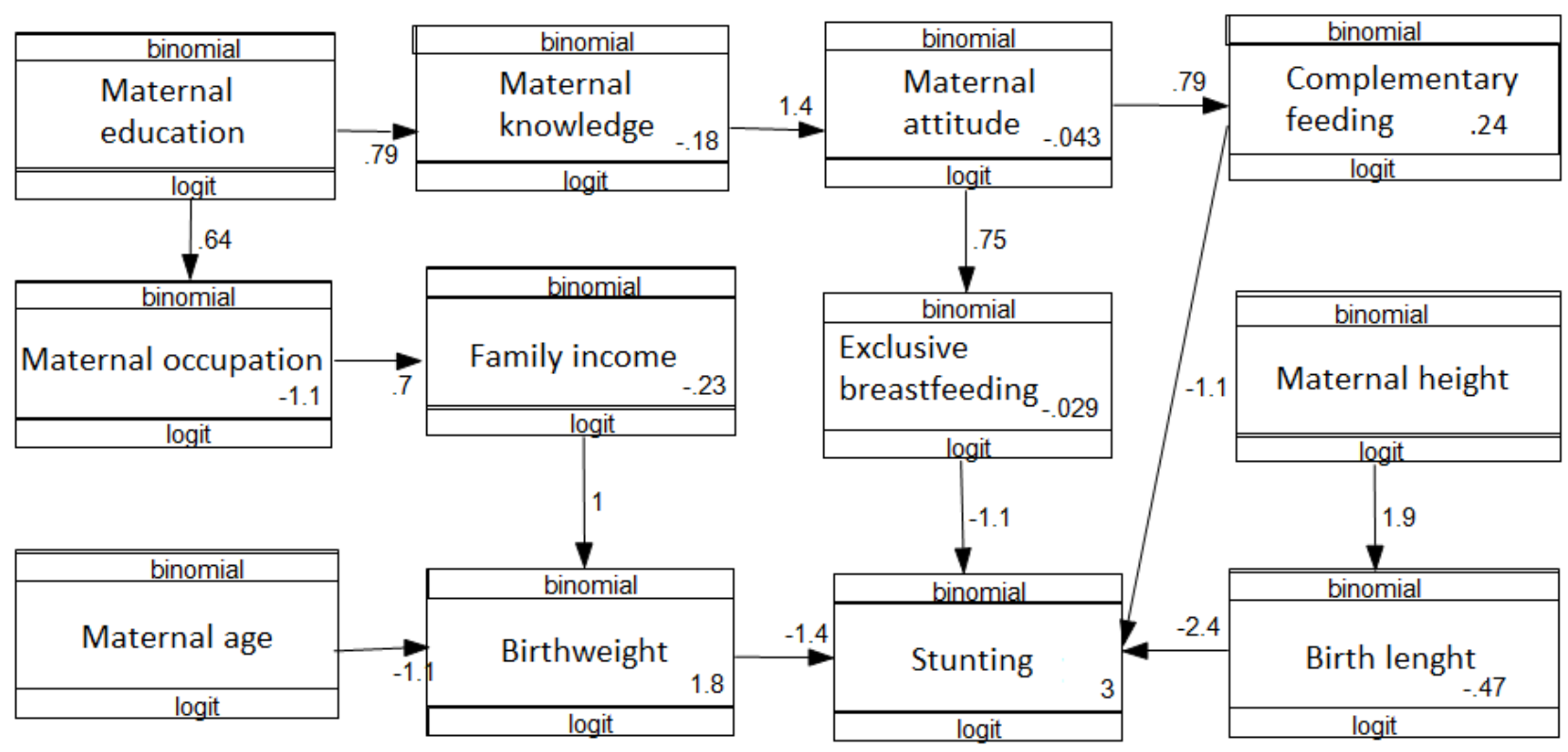

Figure 1. Structural Model of Path Analysis

Table 3. The results of path analysis

\begin{tabular}{|c|c|c|c|c|}
\hline & & & & \\
\hline $\begin{array}{l}\text { Dependent } \\
\text { Variable }\end{array}$ & IndependentVariabel & $\mathbf{b}$ & $\begin{array}{r}\text { Lower } \\
\text { Limit }\end{array}$ & $\begin{array}{l}\text { Upper } \\
\text { Limit }\end{array}$ \\
\hline
\end{tabular}

\section{Direct Effect}

Stunting

Indirect Effect

Birth weight

Timely comple-

mentary feeding

Exclusive

breastfeeding

Family Income

Attitude

Occupation

Knowledge

Birth length

N Observation

$\leftarrow$ Birth weight $(\geq 2500$ gram $)$

$\leftarrow$ Birth length $(\geq 48 \mathrm{~cm})$

$\leftarrow$ Timely complementary feeding

$\leftarrow$ Exclusive breastfeeding

$\leftarrow$ Family Income $(\geq \operatorname{Rp} 1,800,000)$

$\leftarrow$ Maternal age $(<20$ or $\geq 35$ year old

$\leftarrow$ Maternal attitude (positive)

$\leftarrow$ Maternal attitude (positive)

$\leftarrow$ working outside of house

$\leftarrow$ good knowledge

$\leftarrow$ Education ( $\geq$ Senior high school)

$\leftarrow$ Education ( $\geq$ Senior high school)

Maternal height $(>150 \mathrm{~cm})$

Log likehood $=-10009$

$\mathrm{AIC}=2063.25$

$\mathrm{BIC}=2135.81$

There was an indirect and positive effect of work on stunting through family income, and the effect was statistically significant. Children with mothers who 
work outside the home have logodd to experience high family income of 0.70 units higher than maternal work in the home $(\mathrm{b}=$ 0.70 ; CI $95 \%=0.09$ to $1.32 ; \mathrm{p}=0.025$ ). There was an indirect and positive effect of knowledge on stunting through attitudes, and the effect was statistically significant. Children with positive maternal attitudes had logodd to experience good maternal knowledge of 1.41 units higher than negative attitudes $(b=1.41 ; 95 \% \mathrm{CI}=0.79$ to $1.32 ; \mathrm{p}<0.001)$.

There was an indirect and positive effect of education on stunting through work and knowledge. Children with high maternal education had logodd to experience working mothers outside the home by 0.79 units higher than low maternal education $(b=0.79$; $95 \% \mathrm{CI}=0.02$ to 1.25 ; $\mathrm{p}=0.041)$ and children with high maternal education had logodd to experience knowledge women with a total of 0.79 units were higher than low maternal education $(b=$ $0.79 ; 95 \% \mathrm{CI}=0.21$ to $1.36 ; \mathrm{p}=0.007$ ). There was an indirect and positive effect of maternal height on stunting through birth length, and the effect was statistically significant. Children with maternal height $>150 \mathrm{~cm}$ had logodds to experience birth length $>48 \mathrm{~cm}$ at 1.87 units higher than maternal height $<150 \mathrm{~cm}(\mathrm{~b}=1.87$; $\mathrm{CI} 95 \%$ 0.70 to $3.04 ; \mathrm{p}=0.007$ ).

\section{DISCUSSION \\ 1. The effect of infant birth weight on stunting in children aged 2-3 years}

The results showed that there was a significant effect of infant birth weight on the incidence of stunting. Birth weight is one of the determinants of stunting factors (Rahayu et al., 2018). Low birth weight influenced the growth and development of a baby that was slower than the baby born with normal weight.
Infants with low birth weight since the womb had experienced inter-uterine inter-growth retardation and could continue until the next age after birth that is experiencing slower growth and development than those born to normal, and had an impact on failure to grow and develop according to age. Based on studies conducted, it was shown that low birth weight babies had a risk of 10.51 times for stunting compared to normal birth weight (Lestari et al., 2018).

\section{The effect of birth length on stunt- ing in children aged 2-3 years}

The results showed that there was a significant effect between birth length on the incidence of stunting. Stunting reflects the inability to achieve optimal growth caused by health status and / or suboptimal nutritional status (Rahmadi, 2016). Short birth length will have an impact on the child's height in early childhood and adulthood (Dorelien, 2016).

Short-born body lengths have a 2.4 times risk for stunting at ages 6-12 months compared to children who have normal birth lengths (Rahayu, 2011). Rahmawati et al (2018) explained that body length $\geq 48$ $\mathrm{cm}$ had a risk of 0.90 times for not experiencing stunting compared to birth length $<48 \mathrm{~cm}$.

\section{The effect of complementary feed- ing on stunting in children aged 2- 3 years}

The results showed that there was a significant influence between timely complementary feeding on stunting. Timely complementary feeding was one of the factors that influence the incidence of stunting (Ministry of Republic of Indonesia, 2012). Akram et al. (2018) explained that stunting is influenced by the administration of complementary feeding too early (infants less than 6 months) and the occurrence of infectious diseases (diarrhea). Giving food 
and drinks other than breast milk in infants aged o-6 months caused babies to experience digestive disorders one of which was diarrhea and if the treatment was not good it can lead to stunting in children.

According to Uwiringiyimana et al. (2019) explained that the timely complementary feeding reduces the incidence of stunting. Giving complementary feeding by giving zinc supplements has the possibility of 1.89 to increase body weight seen from the $\mathrm{z}$-score compared to those not given supplements.

\section{The effect of exclusive breastfeed- ing on stunting in children aged 2- 3 years}

The results showed that there was a significant effect between exclusive breastfeeding on the incidence of stunting. Failure of growth after birth is a reflection of exclusive breastfeeding that is less precise and causes stunting (Rahmadi, 2016). The effort to reduce the incidence of stunting is to optimize exclusive breastfeeding for 6 months.

Proper exclusive breastfeeding can provide protection against gastrointestinal infections that can cause nutritional depletion that causes stunting (Kramer and Kakuma, 2012). Lestari et al. (2018) explained that exclusive breastfeeding can reduce the incidence of stunting which has a 0.23 times probability of not stunting compared to those who are not given exclusive breastfeeding.

\section{The effect of family income on stunting in children aged 2-3 years}

The results showed that there was a significant effect between family income on the incidence of stunting.

Family income during pregnancy increases development in children through the birth weight of the child, thereby reducing the incidence of stunting (Conant et al., 2017). Families with high income have the ability to meet nutritional needs and choose good health services for children so that they will prevent infectious diseases that cause stunting.

Nshimyiryo et al. (2019) explained that family income has an important role in providing an effect on the welfare and health-oriented standard of living, thereby reducing the possibility of stunting.

\section{The effect of maternal age on stunting in children aged 2-3 years}

The results showed that there was a significant influence between the age of the mother during pregnancy on the incidence of stunting. According to Jiang (2015), pregnant women over the age of 35 have a risk of giving birth to stunting children 2.74 times compared to mothers who give birth at the age of 25-35 years.

Asiyah et al. (2010) also explained that pregnancies with a gestational age of 20-35 years are a safe period because of the maturity of the reproductive and mental organs for pregnancy and childbirth. A study conducted by Fall et al. (2015) showed that children from mothers less than 19 years old have higher risk of experiencing impaired growth so that they are quite short in age at 2 years by $30-40 \%$.

\section{The effect of maternal attitude on stunting in children aged 2-3 years} The results showed that there was a significant effect between maternal attitudes toward the incidence of stunting through complementary feeding and exclusive breastfeeding. According to Mardewi et al (2016), a positive attitude is one of the determinants of factors that influence exclusive breastfeeding.

The results of the study of Astuti and Isroni (2013) showed that there was a relationship between attitude and exclusive breastfeeding behavior. Mothers with positive attitudes towards exclusive breastfeeding have the possibility to give exclusive 
breastfeeding compared to mothers who are negative (Vijayalakshmi et al., 2015). Kismul et al. (2018) exclusive breastfeeding can reduce stunting because the calcium content in breast milk is more efficiently absorbed. Indicators that need to be considered in the administration of complementary feeding are the age of giving complementary feeding, the type of complementary feeding, the frequency of complementary feeding, the portion complementary feeding, and the provision of complementary feeding in early stages (Lestari, 2014). Tessema (2013) explained that mother's positive attitude towards complementary feeding provides an important role for fulfilling infant nutrition and is able to stimulate eating skills and self-confidence in infants.

\section{The effect of maternal occupation on stunting in children aged 2-3 years}

The results showed that there was a significant effect between the occupation of mothers on the incidence of stunting. Mardiyanti and Kurniawati (2014) explain that highly educated women are usually busy with activities outside the home because of work, but by working, mothers are able to increase family income so that the tendency to meet family food needs is better. The higher the family income, the mother tends to switch to formula milk so that the mother no longer gives ASI to her baby (Susiloretni, 2014). Illahi (2017) explains that mothers who work outside the home can cause children to be poorly cared for so that the pattern of parenting will be affected and fulfill the child's nutritional needs thereby increasing the chances of stunting.

\section{The effect of knowledge on stunt- ing in children aged 2-3 years}

The results showed that there was a significant effect between maternal knowledge on the incidence of stunting. Kamiyaet al (2018) explained that negative maternal attitudes related to food had an effect on negative maternal actions and behaviors which had an impact on children's nutritional problems, one of which was stunting.

According to Zainudin (2014), poor nutrition knowledge of mothers is influenced by the attitude of lack of care about nutrition, so that it will have an impact on the growth and development of their children. Based on the results of the study, it was found that there was a direct influence on birth length, infant birth weight, exclusive breastfeeding and MP-ASI and was directly influenced by family income, maternal age, maternal attitudes, maternal height, occupation, education, and knowledge.

\section{The effect of maternal education on stunting in children aged 2-3 years}

The results showed that there was a significant influence between education on the incidence of stunting through work and knowledge. Alfianrisa et al (2017) explained that high education is related to the occupation of mothers outside the home, thereby reducing exclusive breastfeeding and increasing the risk of stunting. According to Garti et al (2018) mothers who work at home can apply more time to provide the best parenting style and mothers can focus more on caring for children and influencing better child development. Mothers who work outside the home have 5.38 times the risk of stunting compared to housewives. Maternal education is useful in receiving information about nutrition and external health problems so that the mother is able to choose and serve food for the family and reduce the incidence of stunting (Makoka and Masibo, 2015).

A study conducted by Abuya et al (2015) shows that low education <high 
school had a risk of 1.28 times the occurrence of stunting compared to children whose mothers are highly educated.

\section{The effect of maternal height on stunting in children aged 2-3 years}

The results showed that there was a significant effect between maternal height on the incidence of stunting in children aged 2-3 years. The determinant of the factors that influence birth length is one of them is maternal height (Addo et al., 2013).

According to Sinha et al (2018) birth length is influenced by maternal height because it is based on biological aspects associated with internal factors, namely factors from the mother (genetic factors) so that it is associated with the incidence of stunting. The results of the study are in line with the study conducted by Indriyani et al (2018) showing that mothers with $<150 \mathrm{~cm}$ maternal height had a risk of 1.39 times to have children with birth length $<48 \mathrm{~cm}$ thus increasing the risk of stunting.

Based on the results of the study, it can be concluded that there was a direct influence of birth length, infant birth weight, exclusive breastfeeding and MPASI and is directly influenced by family income, maternal age, maternal attitudes, maternal height, occupation, education and knowledge.

\section{AUTHOR CONTRIBUTION}

Baroroh Barir was the main author who played a role in collecting and processing the data. Bhisma Murti and Eti Poncorini Pamungkasari examined the framework of research concepts and methodologies.

\section{FUNDING AND SPONSORSHIP}

This study was self-funded.

\section{CONFLICT OF INTEREST}

There is no conflict of interest.

\section{ACKNOWLEDGMENT}

We would like to thank Bhisma Murti and Eti Poncorini Pamungkasari who reviewed this study. We also thank the public health centers for helping with the study and the participating mothers and children who were willing to be the subjects.

\section{REFERENCES}

Abuya BA, Ciera J, Kimani-Murage A (2012). Effect of Mother's Education On Child's Nutritional Status in The Slums of Nairobi. BMC Pediatrics. 12: 8o.https://doi.org/10.1186/1471243112-80.

Addo Y, Stein AD, Fall $\mathrm{CH}$, Gigante DP, Guntupalli AM, Horta BL, Kuzawa CW et al(2013). Maternal Height and Child Growth Patterns. The Journal Ofpediatrics, 163(2). https://doi.org/10.1016/j.jpeds.2013.02.002.

Akram R, Sultana M, Ali N, Sheikh N, Sarker RA (2018). Prevalence and determinants of stunting among preschool children and its urban-rural disparities in Bangladesh. Food and Nutrition Bulletin, 163(4): 549-554. https://doi.org/10.1177/03951179477 o.

Alfianrisa A, Salimo H, Pamungkasari EP. (2017). Factors associated with exclusive breastfeeeding: Application of PRECEDE-PROCEED model and theory of planned behavior. Journal of Maternal and Child Health, 2(1): 42-53. https://doi.org/10.26911/thejmch.2017.02.01.05.

Armstrong MEG, MI Lambert, EV Lambert (2011). Secular trends in the prevalence of stunting, overweight and obesity among South African Children 
(1994-2004). European Journal of Clinical Nutrition, 65(7): 835-840. https://doi.org/10.1038/ejcn.2011.46.

Asiyah S (2010). Karakteristik bayi berat lahir rendah sampai tribulan II tahun 2009 di Kota Kediri (Characteristics of Low Birth Weight Babies up to Quarter II of 2009 in the City of Kediri). Jurnal Kesehatan Suara Forikes, 1(3): 210-222.

Astuti I (2013). Determinan pemberian ASI eksklusif pada ibu menyusui (Determinants of Exclusive Breastfeeding for Breastfeeding Mothers). Jurnal Health Quality, 4(1): 1- 76 .

Conant LL, Einat L, Anjali D, Binder JR (2017). The relationship between maternal education and the neural substrates of phoneme perception in children: Interactions between socioeconomic status and proficiency level. Brain \& Language, 171: 14-22. https://doi.org/10.1016/j.bandl.2017. 03.010.

Dorélien AM (2016). Effects of birth month on child health and survival in SubSaharan Africa. Public Access, 61(2): 209-230. https://doi.org/10.1080/19485565.2015.1032399.

Fall CHD, Sachdev HS, Osmond C, Restrepo-Mendez MC, Victora C, Martorell R, Stein AD, et al. (2015). Association between maternal age at childbirth and child and adult outcomes in the off spring: A prospective study in five low-income and middle-income countries (COHORTS Collaboration). Lancet Glob Health, 3(7): e366-77. https://doi.org/10.1016/S2214109X(1 5)00038-8.

Garti H, Ali Z, Gart HA (2018). Maternal daily work hours affect nutritional status of children in Northern Ghana. Nutrire, 43: 16. https://doi.org/10.1186/s41110-018-0075-0.
Huda TM, Hayes A, Arifeen SE, Dibley MJ (2017). Social determinants of inequalities in child undernutrition in Bangladesh: a Decomposition Analysis. Matern Child Nutr, 14(1): e12440. https://doi.org/10.1111/mcn.12440.

Illahi RK (2017). Hubungan pendapatan keluarga, berat lahir, dan panjang lahir dengan kejadian stunting balita 24-59 bulan di Bangkalan (The relationship between family income, birth weight, and length of birth with the incidence of stunting toddler 24-59 months in Bangkalan). Jurnal Manajemen Kesehatan, 3(1): 1 - 14. https://doi.org/10.29241/jmk.v3i1.85

Indriyani E, Dewi YLR, Salimo H (2018). Biopsychosocial determinants of stunting in children under five: a path analysis evidence from the border area West Kalimantan. Journal of Maternal and Child Health, 3(2): 146155. https://doi.org/10.26911/thejmch.2018.03.02.07.

Jiang YSX, Wang C, Zhang L, Zhang X, Wang L, Cui Y (2014). Prevalence and risk factors for stunting and severe stunting among children under three years old in Mid-Western Rural Areas of China. Child: Care, Health and Development, 41(1): 45-51. https://doi.org/10.1111/cch.12148

Kamiya Y, Nomura M, Ogino H, Yoshikawa K, Siengsounthone L, Xangsayarath P (2018). Mothers' autonomy and childhood stunting: Evidence from semiurban communities in Lao PDR. BMC Women's Health, 18(1): 70.DOI. https://doi.org/10.1186/s12905-0180567-3.

Kemenkes RI (2015). Situasi dan Analisis ASI Eksklusif. Jakarta: InfoDATIN.

Kismul H, Acharya P, Mapatano MA, Hatløy A (2018). Determinants of childhood stunting in the democratic 
Republic of Congo: furtheranalysis of Demographic and Health Survey 2013-14. BMC Public Health, 18:74 https://doi.org/10.1186/s12889-0174621-0.

Kusumawati E, Rahardjo S, Sari HP (2015). Model pengendalian faktor risiko stunting pada anak usia di bawah tiga tahun. Jurnal Kesehatan Masyarakat Nasional, 9(3): 249-256. http://dx.doi.org/10.21109/kesmas.v9i3.572.

Lestari ED, Hasanah F, Nugroho NA (2018). Correlation between nonexclusive breastfeeding and low birth weight to stunting in children. Paediatr Indonesia, 58(3). https://doi.org/10.14238/pi58.3.2018.123-7

Lestari MU, Lubis G, Pertiwi D (2014). Hubungan pemberian makanan pendamping ASI (MP-ASI) dengan status gizi anak usia 1-3 tahun di Kota Padang tahun 2012 (Relationship between giving complementary foods for breast milk with nutritional status for children aged 1-3 years in Padang City in 2012). Jurnal Kesehatan Andalas, 3(2).

Makoka D, Masibo PK (2015). Is there a threshold level of maternal education sufficient to reduce child undernutrition? Evidence from Malawi, Tanzania and Zimbabwe. BMC pediatrics, 15(1): 96. https://doi.org/10.1186/s12887-015-0406-8.

Mardewi KW, Sidiartha IGL, Gunawijaya E. (2016). Low serum zinc and short stature in children. Paediatr Indones, 56(3). https://doi.org/10.14238/pi56.3.2016.171-5 .

Mardiyanti L, Kurniawati LD (2014). Pola asuh orang tua mempengaruhi perkembangan balita di posyandu Arjuna RW IV Pos 3 Kelurahan Kemayoran Kecamatan Krembangan Surabaya (Parenting influence the development of toddlers in Posyandu Arjuna RW IV Pos 3 Kemayoran Village, Krembangan District, Surabaya). Jurnal Ilmiah Kesehatan, 7(12): 9-16. http://journal.unusa.ac.id/index.php /jhs/article/view/47/43

Nshimyiryo A, Hedt-Gauthier B, Mutaganzwa C, Kirk CM, Beck K, Ndayisaba A, Mubiligi J, et al. (2019). Risk factors for stunting among children under five years: A cross-sectional population-based study in Rwandau sing the 2015 Demographic and Health Survey. BMC Public Health, 19: 175. https://doi.org/10.1186/s12889-0196504-z.

Onis M, Branca F (2016). Childhood stunting: a Global Perspective. Maternal \& Child Nutrition,12(1): $12 \quad-\quad 26$. https://doi.org/10.1111/mcn.12231.

Rahayu LS (2011). Associated of Health of Parents with changes of Stunting from 6-12 months to 3-4 years (Tesis): Yogyakarta, Universitas Gajah Mada.

Rahayu RM, Pamungkasari EP, Wekadigunawan CPS (2018). The biopsychosocial determinants of stunting and wasting in children aged 12-48 months. Journal of Maternal and Child Health, 3(2): 105-118. https://doi.org/10.26911/thejmch.20 18.03.02.03.

Rahmadi A (2016). Hubungan berat badan dan panjang badan lahir dengan kejadian stunting anak 12-59 bulan di Provinsi Lampung. Jurnal Keperawatan, $7(2)$.

Rahmawati VE, Pamungkasari EP, Murti B (2018). Determinants of stunting and child development in Jombang District. Journal of Maternal and Child Health, 3(1): 68-80. https://doi.org/10.26911/thejmch.2018.03.01.07.

Riskesdas (2018). Hasil Utama Riskesdas 2018. Kementerian Kesehatan Badan 
Journal of Maternal and Child Health (2019), 4(6): 486-498

https://doi.org/10.26911/thejmch.2019.04.06.09

Penelitian dan Pengembangan Kesehatan.

Singh A, Upadhyay AK, Kumar K (2016). Birth size, stunting and recovery from stunting in Andhra Pradesh, India: Evidence from the Young Lives Study. Maternal and Child Health Journal. Springer US. https://doi.org/10.1007/s1099501621328.

Sinha B, Taneja S, Chowdhury R, Mazumder S, Rongsen-Chandola T, Upadhyay RP, Martines J, et al. (2018). Lowbirthweight infants born to shortstature mothers are at additional risk of stunting and poor growth velocity: Evidence from secondary data analyses. Matern Child Nutr. 14: e12504. https://doi.org/10.1111/mcn.12504.

Susiloretni KA (2014). Family approach to overcome child stunting: is a must. Politeknik Kesehatan Malang. https://www.researchgate.net/publication/328736300.
Tessema M, Belachew T,Ersino G (2013). Feeding patterns and stunting during early childhood in rural communities of Sidama, South Ethiopia. Pan Afr Med J, 14: 75. https://doi.org/10.11604/pamj.2013.14.75.1630

Uwiringiyimana V, Marga C, Amer S, Veldkamp A (2019). Predictors of stunting with particular focus on complementary feeding practices: A cross-sectional study in the Northern Province of Rwanda. Nutrition, 60: 11-18. https://doi.org/10.1016/j.nut.2018.07.016.

Vijayalakshmi P, Susheela T, Mythili D (2015). Knowledge, attitudes, and breastfeeding practices of postnatal mothers: A cross sectional survey. International Journal of Health Sciences. Qassim University, 9(4): 364374. PMID: 26715916.

Zainudin A (2014). Teknologi Pangan. Yogyakarta: CV Idea Sejahtera. 